\title{
The Host of Heaven and the Divine Army: A Reassessment
}

\author{
CAT QUINE \\ cat.quine@nottingham.ac.uk \\ University of Nottingham, Nottingham, NG7 2RD, United Kingdom
}

\begin{abstract}
That YHWH was perceived to command a divine army in the heavens brooks no argument. Traditionally, the phrase "host of heaven" (צבא השמים) has been associated with this divine army. In this article I reassess the relevant evidence and argue that the host of heaven are not portrayed in this role. The biblical texts contain numerous references to YHWH's divine army, but these forces are never called a host (צבא). Rather, the diversity of terminology employed in reference to YHWH's army suggests that it possessed no fixed terminology. It may be that the biblical authors deliberately did not use the term host in order to avoid associating YHWH's divine army too closely with the weaknesses of human armies.
\end{abstract}

That YHWH was believed to command a divine army is not in doubt. The צבא (צשה regularly refers to human armies in the biblical corpus, and thus the צבא השמים are commonly associated with the divine army in scholarly literature and popular conception. ${ }^{1}$ In this article, however, I will demonstrate that, in the biblical texts, "the host of heaven" are never portrayed as a military force or as acting in a military manner. ${ }^{2}$

This article is the result of research undertaken for my doctoral thesis: Cat Quine, "Ritual, Rhetoric, and the Polemic against the Host of Heaven" (PhD diss., University of Nottingham, 2018), funded by Midlands4Cities AHRC Doctoral Training Partnership. Thanks are due to my funders and my supervisor, Prof. Carly L. Crouch, for her comments on earlier drafts of this material.

${ }^{1}$ E.g., E. Theodore Mullen Jr., "Hosts, Host of Heaven," ABD 3:301-4; Bernhard W. Anderson, "Hosts, Hosts of Heaven," NIDB 2:655-56; Fabrizio Lelli, "Stars," DDD, 809-15, here 813; Ida Zatelli, "Astrology and the Worship of the Stars in the Bible," ZAW 103 (1991): 86-99, here 87. While it is clear that the term צבא often refers to the human armies-see, e.g., DCH 7, s.v. "צבא"; HALOT, s.v. "צבא"-Herbert Niehr cautions that very few examples of a military background of the host of heaven have been preserved, and he offers only Dan 8:10-11 (cf. Josh 5:13-15) as potential examples ("Host of Heaven," $D D D, 428-30$ ), both of which are discussed here.

${ }^{2}$ This study is confined to the Hebrew Bible. Although later Jewish texts develop themes 
While this may not prove beyond doubt that the host of heaven were never conceived of as a divine army, it should demonstrate that caution is needed when dealing with "the host of heaven" and that it is necessary to consider why YHWH's army is not called a host. In the first section, I explore texts that mention a (potentially divine) "host" near a military context and are sometimes claimed to reflect the involvement of the divine army in warfare (Isa 13:2-5, Josh 5:13-15, Dan 8:1014). As I will demonstrate, these texts do not reflect the host of heaven acting in a military manner but are better interpreted as portraying human armies (Isa 13), divine command of a human army (Josh 5) or divine worshipers (Dan 8). The second section focuses on texts that refer to celestial bodies in military conflict but do not mention a "host" or "the host of heaven," namely, Judg 5:20 and Josh 10:1214. The presence of celestial bodies in divine military conflicts does not necessarily support claims that the host of heaven were YHWH's divine army. In the third section, I examine the other portrayals of YHWH's divine army, observing that this army is never called a "host" or "the host of heaven." Rather, the biblical texts use a variety of terms to portray YHWH's military forces. Consequently, it appears that there was no fixed idea of, or terminology for, YHWH's divine army. Furthermore, this variance may be deliberate as it seems that the authors avoided portraying YHWH's army in terms that too closely mirrored human armies. Whereas Israel's and Judah's armies were called צבא and were comparatively small and regularly defeated, YHWH's army is never called a צבא and is described in supernatural terms emphasizing its miraculous nature and enduring power.

\section{A Divine Military "Host"?}

There are three texts to consider in this section: Isa 13:2-5, Josh 5:13-15, and Dan 8:10-14. Each of these texts has, at times, been interpreted as reflecting the host of heaven portrayed as YHWH's divine army.

The first of these, Isa 13:2-5, is located at the beginning of an oracle against Babylon (Isa 13-14). The passage is often dated to the sixth century BCE on account of its portrait of Babylon as a superpower soon to fall and the mention of the Medes as having a hand in this downfall (13:17). ${ }^{3}$ Isaiah 13:2-5 narrates YHWH's

found in the Hebrew Bible in their own way, I prefer to interpret the Hebrew Bible texts in their own contexts before applying later theological developments and ideas. The same is true of earlier nonbiblical texts, such as those found at Ugarit. Since there may be temporal and cultural gaps between the nonbiblical texts and the Hebrew Bible, I focus solely on the Hebrew Bible here to address the question, How does the Hebrew Bible portray the host of heaven?

${ }^{3}$ E.g., Joseph Blenkinsopp, Isaiah 1-39: A New Translation with Introduction and Commentary, AB 19 (New York: Doubleday, 2000), 277; Hans Wildberger, Jesaja, 3 vols., BKAT 10 (Neukirchen-Vluyn: Neukirchener Verlag, 1978), 2:507-11; H. G. M. Williamson, The Book Called Isaiah: Deutero-Isaiah's Role in Composition and Redaction (Oxford: Oxford University

This article was published in JBL 138/4 (2019) 741-755, copyright @ 2019 by the Society of Biblical Literature. To purchase copies of this issue or to subscribe to JBL, please contact SBL Customer Service by phone at 866-727-9955 [toll-free in North America] or 404-727-9498, by fax at 404-727-2419, or visit the online SBL Store at www.sbl-site.org. 
summoning of an army from the ends of the heavens and earth in preparation for battle. The identity of the army is unclear: 13:3 refers to YHWH commanding his "consecrated ones" (למקדשי) and his "warriors" (גבורי) to execute his anger. Meanwhile, 13:4 reports the sound of kingdoms and nations gathering as YHWH musters his "host" for war (יהוה צבאות מפקד צבא מלחמה). The army are described in 13:5 as coming from far-off lands and the end of the heavens. ${ }^{4}$ Although the mention of the end of the heavens seems to set the stage for a mention of the divine army, the "warriors" (גבורי) and "consecrated ones" (למקדשי) are usually interpreted as humans. ${ }^{5}$ John D. W. Watts explains the reference to consecration via recourse to warriors' purification rituals before battle. ${ }^{6}$ The mention of the army gathering from disparate locations (distant land, end of the heavens) has been explained as reflecting the fact that armies were often formed of groups of people and individuals from diverse backgrounds and origins. ${ }^{7}$ Though this is true of human armies, the divine army is never described as such a conglomeration of different groups and beings, and notably the mention of the "end of the heavens"the only divine element mentioned in the passage-occurs in the final verse (13:5), serving as a climax rather than a background to events. It thus seems that there is a progression in Isa 13:2-5. The first verses (13:2-3) portray the gathering of the army in human terms, while 13:4-5 depicts the scene in ever more climactic and cosmic terms, culminating with the threat to destroy the whole earth (13:5). The army of Isa 13:2-5-that is, the "host for war" (צבא מלחמה) that YHWH mustersseems, therefore, to be envisaged as a human army acting with cosmic significance. This also fits with the depiction of the enemy to be fought; in Isa 13-14 Babylon is not merely a human opponent of Israel but is presented as a symbol of cosmic

Press, 1994), 158. As with the dating of any biblical text, however, disagreements exist; Seth Erlandsson (The Burden of Babylon: A Study of Isaiah 13:2-14:23, ConBOT 4 [Lund: Gleerup, 1970]) advocates for an eighth-century date for the passage, while Bernard Gosse (Isaïe 13,1-14,23 dans la tradition littéraire des oracles contre les nations, OBO 78 [Freiburg, Switzerland: Universitäts Verlag; Göttingen: Vandenhoeck \& Ruprecht, 1988], 167) argues for a postexilic date.

${ }^{4}$ This description may evoke the "superhuman" army in Isa 5:26-29, who are indefatigable. Gosse, for example, argues that Isa 13:2-5 takes up 5:26-29 and amplifies it (Isaïe 13,1-14,23, 124). Notably, however, while the army of Isa 5 is portrayed as strong and undefeatable, it does not refer to a divine army, since it uses the term גוים ("nations"), which is never applied to the divine armies. Isaiah 13:2-5 may take up an idea present in 5:26-29, therefore, but this does not necessitate an interpretation of a divine host in 13:2-5.

${ }^{5}$ Wildberger interprets the army as the Medes, who would defeat Babylon (Jesaja, 2:507). Ronald E. Clements, meanwhile, argues that they are the Babylonians who would wreak havoc on Judah before having events reversed upon themselves (Isaiah 1-39, NCBC [London: Marshall, Morgan \& Scott, 1980], 132-33). Gosse notes that גבור denotes professional soldiers (Isaïe 13,1$14,23,126)$.

${ }^{6}$ John D. W. Watts, Isaiah 1-39, WBC 24 (Waco, TX: Word, 1985), 196.

${ }^{7}$ Georg Fohrer, Das Buch Jesaja, 3 vols., ZBK 19 (Zurich: Zwingli, 1960), 1:166. 
opposition to YHWH's rule. The army that will defeat it, therefore, is human but acts on a cosmic scale.

Differently, Josh 5:13-15 deals with an individual. It narrates the appearance to Joshua of the "commander of the host of YHWH" (שר־צבא־יהוה). This figure has been interpreted as military in nature due to his bearing a drawn sword (Josh 5:13), the mention of צבא, and the location of the verses, just prior to the conquest of Jericho (Josh 6). He has been variously described as a leader of the heavenly armies, as a divine counterpart to Joshua (implying that he was leader of the heavenly armies), and as a reflection of the synergy between the human and divine armies of Israel and YHWH. ${ }^{8}$ Other divine figures, however, appear bearing drawn swords in the Hebrew Bible and are not interpreted as part of the divine army, for example, מלאך יהוה ("the messenger of YHWH”) figures in Num 22:23 and 1 Chr 21:16. The similarity between these מלאד יהוה figures and the figure of Josh 5:13-15 has been previously noted and may suggest that the conception the author has in mind was that of a מלאך, but expressed with different terminology. ${ }^{9}$ Notably, while not unique, the title שר־צבא appears elsewhere only once, in the much later Dan 8:10, where it is usually translated "prince of the host" and refers to YHWH. Furthermore, although the figure appears just before the conquest of Jericho in Josh 6 , he is not actually mentioned in that chapter, and in 5:13-15 he does not act in any military manner. Nor does he need to, for the appearance of a divine figure bearing weapons before a battle was a good omen in the ancient Near East. ${ }^{10}$ The location of 5:13-15 prior to the conquest of Jericho is thus logical-the figure's presence serves as a good omen, a reassurance of divine support for the coming battle.

The figure tells Joshua to remove his sandals for he is standing on holy ground. This message is immediately evocative of Exod 3:5, where YHWH tells Moses to remove his sandals at the burning bush, and seems intended to set Joshua in the

${ }^{8}$ E.g., Volkmar Fritz, Das Buch Josua, HAT 1/7 (Tübingen: Mohr Siebeck, 1994), 63; Daniel L. Hawk, Joshua, Berit Olam (Collegeville, MN: Liturgical Press, 2000), 83; Robert G. Boling and G. Ernest Wright, Joshua: A New Translation with Introduction and Commentary, AB 6 (New York: Doubleday, 1982), 198; Patrick D. Miller, The Divine Warrior in Early Israel, HSM 5 (Cambridge: Harvard University Press, 2013), 13.

${ }^{9}$ Trent C. Butler, Joshua, WBC 7 (Nashville: Nelson, 1983), 61; Boling and Wright, Joshua, 198; Miller, Divine Warrior, 129.

${ }^{10}$ See John Van Seters, “Joshua's Campaign of Canaan and Near Eastern Historiography," in Israel's Past in Present Research: Essays on Ancient Israelite Historiography, ed. V. Philips Long, SBTS 7 (Winona Lake, IN: Eisenbrauns, 1999), 170-80, esp. 178-79; Thomas Römer, “Joshua’s Encounter with the Commander of Yhwh's Army (Josh 5.13-15): Literary Construction or Reflection of Royal Ritual?," in Warfare, Ritual, and Symbol in Biblical and Modern Contexts, ed. Brad E. Kelle, Frank Ritchel Ames, and Jacob L. Wright, AIL 18 (Atlanta: Society of Biblical Literature, 2014), 49-63, here $52 \mathrm{n}$. 9. The appearance of a divine figure could also serve as an etiological element legitimizing a sanctuary or holy place; see, e.g., Martin Noth, Das Buch Josua, HAT 1/7 (Tübingen: Mohr Siebeck, 1971), 37-38.

This article was published in JBL 138/4 (2019) 741-755, copyright ( 2019 by the Society of Biblical Literature. To purchase copies of this issue or to subscribe to JBL, please contact SBL Customer Service by phone at 866-727-9955 [toll-free in North America] or 404-727-9498, by fax at 404-727-2419, or visit the online SBL Store at www.sbl-site.org. 
mold of Moses. ${ }^{11}$ The שר־צבא־יהוה thus fulfills an important literary role-his presence foreshadows divine support for the upcoming conquest(s) of Joshua, while his message simultaneously points backwards to YHWH's appearance to Moses. Furthermore, although צבא often refers to a human army, it also denotes a cultic congregation, and the context of Josh 5 is noticeably dominated by cultic concerns. ${ }^{12}$ Joshua 5:1-12 focuses on the circumcision of the Israelites and Passover, while chapter 6 narrates the fall of Jericho via ritual, rather than military, actions. ${ }^{13}$ We should also bear in mind that YHWH's divine army is never portrayed as having ranks or officers anywhere else in the Hebrew Bible; YHWH is always portrayed at the head of his army as the sole figure of power and authority. In addition, the divine army do not appear anywhere else in the book of Joshua. If the שר־צבאייהוה is to be understood as an officer or commander of the [heavenly] host of YHWH, therefore, this is a unique reference in the entire Hebrew Bible. I find it more likely that this figure represents divine support for the human host of YHWH, manifested through the appearance of a divine being to Israel's leader, in a manner similar to Moses's earlier encounter with YHWH. Admittedly, the title of the figure in Josh 5 is more military than anything seen in Moses's encounter, but, as the text currently stands, the title is only a title-the figure bearing it acts more as a messenger (a (מלאך) than a military commander.

Daniel 8:10-14 is the only other text in the Hebrew Bible that mentions the host of heaven anywhere near military conflict. The passage is widely viewed as an addition (or two: 8:10-12,13-14) to chapter 8 and contains numerous textual complexities. ${ }^{14}$ The passage narrates the actions of the "little horn," usually identified

${ }^{11}$ So Fritz, Das Buch Josua, 63.

${ }^{12}$ Exodus 38:8 refers to women serving at the entrance of the tent of meeting (הצבאת אשר); צבאו), as does 1 Sam 2:22 (הנשים הצבאות); Num 4:3, 23, 30, 35, 39, 43, and 8:24 also use צבת (לאר ) refer to those who are qualified to serve in the tent of meeting (לצבא צבא (לצא); HALOT (Study Edition), s.v. "צבא."

${ }^{13}$ Römer argues that Josh 5 points concentrically back to the Exodus Moses narratives ("Joshua's Encounter," 53-54), and, notably, the ban comes upon Jericho (Josh 6:16-17) after the people of Israel have processed around the city seven times in seven days (Josh 6:1-15). Only when the trumpets were blown on the seventh day did the walls of Jericho fall down and the people of Israel slaughtered the inhabitants (Josh 6:20-21). The emphasis is evidently on the ritual processions rather than on usual military tactics.

${ }^{14}$ E.g., André LaCocque, The Book of Daniel, trans. David Pellauer (London: SPCK, 1979), 156; Reinhard G. Kratz, "The Visions of Daniel," in The Book of Daniel: Composition and Reception, ed. John J. Collins and Peter W. Flint, 2 vols., VTSup 83 (Leiden: Brill, 2001), 1:91-113 (esp. 102-4). Although verses 13-14 are auditory rather than visionary, Collins notes that verses 13-14 are closely linked to verses 11-12 via the use of the shared terms תמיד/פשע, so decisions regarding the authenticity of both sections are interlinked; see John J. Collins, Daniel: A Commentary on the Book of Daniel, Hermeneia (Minneapolis: Fortress, 1993), 328. Furthermore, the variations of verses 11-14 offered in the other textual witnesses suggest that there has been some corruption in the transmission of the verses. The LXX and Theodotion omit צבא in verse 12, reading "stars" and "powers" respectively, and the LXX also seems to guess at its meaning in verse 13, giving "will

This article was published in JBL 138/4 (2019) 741-755, copyright ( 2019 by the Society of Biblical Literature. To purchase copies of this issue or to subscribe to JBL, please contact SBL Customer Service by phone at 866-727-9955 [toll-free in North America] or 404-727-9498, by fax at 404-727-2419, or visit the online SBL Store at www.sbl-site.org. 
as Antiochus IV, who grew as high as the host of heaven and cast down and trampled upon some of the stars $(8: 10) .{ }^{15}$ The actions of Antiochus reflect his arrogance toward YHWH and his disruption of the worship of the Jews. ${ }^{16}$ Daniel 8:12-13 describes Antiochus's transgression of the Yahwistic sanctuary and his violation of the offerings of the Jews, who are called a "host" (צבא, 8:12,13). His casting down of the heavenly host and stars $(8: 10)$ seems to mirror his persecution of YHWH's earthly worshipers $(8: 12,13)$. Although Herbert Niehr seems to view the host of heaven here as YHWH's divine army, there is no contextual evidence to support this; the host do not fight in Dan 8:10—there is no battle. ${ }^{17}$ The host are cast to earth by the arrogant horn, and heaven does not fight back. Here, therefore, the host of heaven seem better understood as heavenly worshipers of $\mathrm{YHWH}$, paralleling the human worshipers on earth (cf. Pss 103:19-22, 148:1-4, Neh 9:6).

This section has explored references to a potentially divine host in military contexts in the Hebrew Bible and found little evidence for a group of beings so often associated with a divine army. Isaiah 13:2-5 seems best understood as referring to a human army that would defeat Babylon. Joshua 5:13-15 has more military potential, but any military interpretation is limited by the lack of military actions undertaken by the divine figure. Meanwhile, in Dan 8:10-14 the host of heaven seem best interpreted as divine worshipers of $\mathrm{YHWH}$, paralleling the Jews whose worship Antiochus IV was disrupting on earth.

\section{A Divine Celestial "Host"?}

Judges 5:20 and Josh 10:12-15 both mention celestial bodies in connection with a battle. Some scholars have thus argued that these texts support the view that

be made desolate" (reading יצדא a צבא צimilarly, the LXX seems uncertain of the meaning of צבא in Dan 10:1; see Tim McLay, The OG and Th Versions of Daniel, SCS 43 (Atlanta: Scholars Press, 1996), 159, 172; Collins, Daniel, 326.

${ }^{15}$ The stars may be an explanatory gloss; see Louis F. Hartman and Alexander A. Di Lella, The Book of Daniel: A New Translation with Introduction and Commentary, AB 23 (New York: Doubleday, 1978), 225, 236; Rainer Stahl, Von Weltengagement zu Weltüberwindung: Theologische Positionen im Danielbuch, CBET 4 (Kampen: Kok Pharos, 1994), 173.

${ }^{16}$ The arrogance of the little horn reaching up to heaven is widely observed to be reminiscent of Isa 14:12-14, and the astral imagery found there may also have contributed to the reference to stars here. See, e.g., Norman W. Porteous, Das Danielbuch, ATD 23 (Göttingen: Vandenhoeck \& Ruprecht, 1962), 103; James A. Montgomery, A Critical and Exegetical Commentary on the Book of Daniel, ICC (1927; repr., Edinburgh: T\&T Clark, 1989), 334; Philip R. Davies, Daniel, OTG (Sheffield: JSOT Press, 1985), 74. Alternatively, Collins notes that, in Egyptian and Greek traditions, the dragon Typhon/Typhoeus assaulted the stars, casting some of them down to earth (cf. Rev 12:4), and these ideas may also have informed the imagery in Dan 8:10 (Daniel, 332-33). LaCocque observes that there may be some irony intended in the image, as Antiochus IV had coins struck bearing his head capped by a star (Book of Daniel, 162 n. 21).

${ }^{17} \mathrm{Niehr}$, "Host of Heaven," 428. 
the host of heaven functioned as YHWH's army. ${ }^{18}$ Yet these texts-and, for that matter, the whole books of Joshua and Judges-never mention the host of heaven (צבא השמים), nor do they refer to the epithet YHWH of hosts (יהוה צבאות), to which I will return further on. Such arguments resemble a syllogism, taking the view that the host were YHWH's army, combining it with the view that the celestial bodies could be called "host of heaven," and concluding, therefore, that the celestial bodies $=$ host of heaven $=$ YHWH's army. ${ }^{19}$ These conclusions are logical enough, but they neglect questions of date, language, and theological developments in different texts. They also fail to observe that the connections between the celestial bodies and the host of heaven occur primarily in polemical texts, which may affect their content. ${ }^{20}$ This section, therefore, explores Judg 5:20 and Josh 10:12-15 closely and, in doing so, demonstrates the lack of correlation between the host of heaven and events reported in these two texts. The stars may fight from heaven (Judg 5:20) and the sun and moon may stop in the sky (Josh 10:12-13), but this does not necessarily shed any light on the host of heaven.

The Song of Deborah (Judg 5) is thirty-one verses in length, yet the battle it narrates takes up only three of these (vv. 19-21). The conflict between the Israelites and the Canaanites is located at Tanaach, by the waters of Megiddo (5:19). The first verse of the battle account mentions the human participants: "the kings came, they fought; then fought the kings of Canaan" (5:19). The Israelites are not mentioned by name-only the kings of Canaan are identified, which is significant because, according to Judges, Israel did not have kings at this point. The next verse, 5:20, progresses from human to divine and states that "the stars fought from heaven, from their courses they fought against Sisera” (מל־מישמים נלחמו הכוכבים ממסלותם) (מלחמו עם־סיסרא before 5:21-22 narrates the flooding of the Wadi Kishon, which

${ }^{18}$ On Judges, see, e.g., Susan Niditch, Judges: A Commentary, OTL (Louisville: Westminster John Knox, 2008), 80; Gösta W. Ahlström, “Judges 5:20f and History," JNES 36 (1977): 287-88; Mark S. Smith, "God in Israel's Bible: Divinity between World and Israel, between Old and New," CBQ 74 (2012): 1-27, here 17; Miller, Divine Warrior, 98. For Joshua, see, e.g., Miller, Divine Warrior, 123-26; and Boling and Wright, Joshua, 284.

${ }^{19}$ The celestial bodies-by which I mean some combination of sun, moon, stars, and planets-are explicitly connected with the host of heaven in four texts: Deut 4:19, 17:3, Jer 8:1-3, and 2 Kgs 23:5. The host are also implicitly connected with the stars (only) in Isa 40:26, 45:12, and Jer 33:22.

${ }^{20}$ As the host of heaven were not limited to astral forms, the authors' presentation of them as the sun, moon, and stars-things that YHWH created-may be a polemical move designed both to disparage astral cults and to highlight the foolishness of those worshiping the host. Something similar may be seen with the biblical authors' treatment of Asherah, whose form and power were undoubtedly not limited to a wooden object in the temple, yet the authors present her this way to disparage her cult and emphasize the futility of idol worship. See discussions in Judith M. Hadley, The Cult of Asherah in Ancient Israel and Judah: Evidence for a Hebrew Goddess, UCOP 57 (Cambridge: Cambridge University Press, 2000), 4-11, 59-63, 77-83; John A. Emerton, "'Yahweh and His Asherah': The Goddess or Her Symbol?," VT 49 (1999): 315-37; Sung Jin Park, “The Cultic Identity of Asherah in the Deuteronomistic Ideology of Israel," ZAW 123 (2011): 553-64.

This article was published in JBL 138/4 (2019) 741-755, copyright ( $\odot 2019$ by the Society of Biblical Literature. To purchase copies of this issue or to subscribe to JBL, please contact SBL Customer Service by phone at 866-727-9955 [toll-free in North America] or 404-727-9498, by fax at 404-727-2419, or visit the online SBL Store at www.sbl-site.org. 
causes the horses of the Canaanites to flee. The interpretation of the role of the stars in this passage remains a matter of debate, though George Foot Moore's proposal that they function as a hypostatic description of YHWH is no longer followed. ${ }^{21}$ Most recent interpretations of these verses connect the actions of the stars with the flooding of the Kishon, albeit in various ways. On the basis of CTA 3 II:30-III:3 (as given in COS 1.86:250-51), which describes 'Anat cleansing herself with rain from the stars after committing her massacre, some interpreters argue that the stars caused a downpour of rain that flooded the Kishon. ${ }^{22}$ Notably, however, no connection between the stars and rain appears anywhere else in the Hebrew Bible. More persuasive is Jeffrey L. Cooley's argument for a causal relationship between the stars and the Kishon on different grounds. Emphasizing the reference to the stars leaving their courses (5:21), Cooley argues that the stars may have left their usual positions, which resulted in an unusual rainfall, flooding the Kishon. ${ }^{23}$ Others propose that, rather than being causally related, the separate forces of the stars and the Kishon joined together to defeat Sisera. ${ }^{24}$ Differently, Jack M. Sasson argues that two separate motifs may be combined in 5:20-21, wherein both stars and flood are set against Israel's enemies. ${ }^{25}$ The extant biblical evidence supports Sasson's view, as both the celestial bodies and waters appear separately as agents of YHWH's judgments in the Hebrew Bible, but nowhere else do the stars and a body of water act in tandem. ${ }^{26}$

${ }^{21}$ George Foot Moore, A Critical and Exegetical Commentary on Judges, 2nd ed., ICC (Edinburgh: T\&T Clark, 1903), 158-59. John F. A. Sawyer's argument for a solar eclipse standing in the background has also not been taken up in scholarship ("From Heaven Fought the Stars [Judg V 20]," VT 31 [1981]: 87-89), nor has Peter C. Craigie's contention that the stars are a poetic reference to Israel's warriors serving under Deborah in a manner comparable to the stars serving 'Anat at Ugarit ("Deborah and 'Anat: A Study of Poetic Imagery," ZAW 90 [1978]: 374-81, here 379-80).

${ }^{22}$ See Joseph Blenkinsopp, "Ballad Style and Psalm Style in the Song of Deborah: A Discussion," Bib 42 (1961): 61-76; Robert Boling, Judges: A New Translation with Introduction and Com mentary, AB 6A (New York: Doubleday, 1975), 113.

${ }^{23}$ This has the advantage of taking seriously the reference in 5:20 to the stars leaving their courses, which most scholars gloss over; see Jeffrey L. Cooley, Poetic Astronomy in the Ancient Near East: The Reflexes of Celestial Science in Ancient Mesopotamian, Ugaritic, and Israelite Narrative, HACL 5 (Winona Lake, IN: Eisenbrauns, 2013), 300-302.

${ }^{24}$ E.g., Andreas G. Scherer, "Der Rhythmus der Schlacht: Die poetische Sprachgestalt von Jdc 5, 19-22," ZAW 117 (2005): 529-42, here 536; Trent C. Butler, Judges, WBC 8 (Nashville: Nelson, 2009), 152.

${ }^{25} \mathrm{He}$ argues this on the basis of an inscription of Sargon of Akkad, which mentions the stars fighting Sargon with no mention of any floodwaters; see Jack M. Sasson, Judges 1-12: A New Translation with Introduction and Commentary, AYB 6D (New Haven: Yale University Press, 2014), 304.

${ }^{26}$ Habakkuk 3:10-11 does place the sun and moon next to the waters, but this passage is a theophany, not a battle. Elsewhere, the celestial bodies are darkened in Isa 13:10, Ezek 32:7, Amos 8:9, Joel 2:10, and 3:10 and appear in battle in Josh 10:12-14, but none of these passages involves

This article was published in JBL 138/4 (2019) 741-755, copyright @ 2019 by the Society of Biblical Literature. To purchase copies of this issue or to subscribe to JBL, please contact SBL Customer Service by phone at 866-727-9955 [toll-free in North America] or 404-727-9498, by fax at 404-727-2419, or visit the online SBL Store at www.sbl-site.org. 
Regardless of the connections with the Kishon, as noted, some view the stars of Judg 5:20 as members of YHWH's host of heaven, fighting at his bidding. ${ }^{27}$ Yet the theophany at the beginning of the chapter (vv. 4-5) does not mention any divine forces that accompany YHWH, nor is YHWH himself, or any command from him to the stars, mentioned in 5:19-22. YHWH is completely absent from these verses. Judges 5 also does not celebrate the outcome of the battle as a victory of YHWH, nor does it ascribe the events of the battle to him..$^{28}$ To view the stars as part of YHWH's divine army in this passage thus requires several interpretive leaps. If the stars are also connected with the Kishon, then the Kishon should be conceived of as part of YHWH's army as well, which seems slightly incongruous. Bodies of water act as agents of YHWH's judgments in the Hebrew Bible, but it would be a stretch to call them part of his army.

Recent research has also drawn attention to the theme of participation versus nonparticipation in YHWH's wars in Judg $5 .{ }^{29}$ This is demonstrated in the contrast, for example, between those tribes who march for YHWH $(5: 12-15)$ and those who stayed behind (5:16-18), or between the curse of Meroz for not answering YHWH's call (5:23) and the praise of Jael for her unanticipated involvement (5:24-27). Jacob L. Wright argues that participation in the war effort was a way for the people to demonstrate their collective identity, and it was therefore significant when certain tribes did not participate in Israel's wars. ${ }^{30}$ When we approach Judg 5 from the perspective of participation and nonparticipation, it is evident that three major parties are missing from the battle account in 5:19-22: YHWH, the Israelites, and the deities of Canaan. The Canaanite gods, in particular, are conspicuous by their absence; the song celebrates the defeat of Sisera but not of his gods. ${ }^{31}$ It is possible, therefore, that the stars could be interpreted as the gods of the kings of

water as an agent of judgment. Meanwhile, water appears (in various forms) as a destructive force, for example, in Isa 8:7-8, Jer 47:2, 51:42, Nah 1:8, and Ps 32:6, but these passages do not involve the celestial bodies.

${ }^{27}$ So Niditch, Judges, 80; Ahlström, “Judges 5:20f," 587-88; Smith, “God in Israel's Bible," 17; Miller, Divine Warrior, 98.

${ }^{28}$ Judges 4:15 seems to correct this, stating explicitly that it was YHWH who defeated Sisera's army and caused them to flee; see the discussion in Baruch Halpern, "The Resourceful Israelite Historian: The Song of Deborah and Israelite Historiography," HTR 76 (1983): 379-401.

${ }^{29}$ Gregory T. K. Wong, “The Song of Deborah as Polemic," Bib 88 (2007): 1-22; Robert H. O'Connell, The Rhetoric of the Book of Judges, VTSup 63 (Leiden: Brill, 1996), 343.

${ }^{30}$ Jacob L. Wright, "Deborah's War Memorial: The Composition of Judges 4-5 and the Politics of War Commemoration," ZAW 123 (2011): 516-34, here 532. This would explain the polemical commemoration of tribes who did not respond to the call to arms in the Song of Deborah.

${ }^{31}$ The close connections between kings and gods in warfare were such that a defeat for a king could imply a defeat for his god, so the absence of the Canaanite gods in a song celebrating Sisera's defeat is perhaps slightly unexpected; see comments on the king-god-warfare relationship in Carly L. Crouch, War and Ethics in the Ancient Near East: Military Violence in Light of Cosmology and History, BZAW 407 (Berlin: de Gruyter, 2009), esp. 21-32.

This article was published in JBL 138/4 (2019) 741-755, copyright ( 2019 by the Society of Biblical Literature. To purchase copies of this issue or to subscribe to JBL, please contact SBL Customer Service by phone at 866-727-9955 [toll-free in North America] or 404-727-9498, by fax at 404-727-2419, or visit the online SBL Store at www.sbl-site.org. 
Canaan who turned against their human kings. If so, the song adds another level of irony to the critique of the Israelite tribes who stayed behind: if even the gods of Canaan turned against their own kings and fought for YHWH, how could YHWH's own tribes refuse to enter the battlefield? Even if this reading is not favorable to all, however, there is nothing explicit in Judg 5 that connects the stars to YHWH's army. No stars or divine army are mentioned alongside YHWH in Judg 5:4-5, nor, indeed, is any divine army of YHWH mentioned in the entire book of Judges. The victory of 5:19-22 is not explicitly ascribed to YHWH or his army, and YHWH is not depicted commanding the stars in Judg 5:20. Moreover, the stars do not fight from heaven anywhere else in the Hebrew Bible. Later texts seem to pick up this connection and theme more strongly, but the Hebrew Bible itself does not reflect it anywhere else (see section III below). We cannot rule out completely that the stars were conceived of as YHWH's army in Judg 5:19-22, but there is very little in the text itself to support the interpretation.

Joshua 10:12-14, meanwhile, narrates a battle between the Israelites and a coalition of Canaanite kings who sought to attack Gibeon and reports that, during the battle, the sun and moon stopped still in the sky when "YHWH fought for Israel" (10:14). The paralysis of the celestial bodies has been variously interpreted. Some have argued that these celestial bodies are part of YHWH's military entourage, though others have tended toward natural phenomena underlying the imagery of the passage, such as an eclipse, a meteorite, or an unusual storm. ${ }^{32}$ Others argue that Joshua prayed for an unnatural extension of daylight so that the battle might last long enough for the Israelites to win..$^{33}$ The east-west opposition of the sun and moon happens in the early morning, however, which does not quite fit with the idea of Joshua praying for more light at the end of the day. Still others point to similarities between Josh 10:12-13 and Mesopotamian astrological omina. ${ }^{34}$

${ }^{32}$ Boling and Wright, Joshua, 284; Miller, Divine Warrior, 123-26. For interpretations of natural phenomena, see, e.g., William J. Phythian-Adams, "A Meteorite of the Fourteenth Century," PEQ 78 (1946): 116-24; and John F. A. Sawyer, "Joshua 10:12-14 and the Solar Eclipse of 30 September 1131 BC," PEQ 104 (1972): 139-46, though an eclipse would require the sun and moon to come together, not to stand in an east-west (Aijalon-Gibeon) opposition. Proponents of the storm theory find support in the mention of stones raining down from heaven in Josh 10:11; see, e.g., John Day, "Gibeon and the Gibeonites in the Old Testament," in Reflection and Refraction: Studies in Biblical Historiography in Honour of A. Graeme Auld, ed. Robert Rezetko, Timothy H. Lim, and W. Brian Aucker, VTSup 113 (Leiden: Brill, 2006), 113-37, here 120-21; Baruch Margalit, “The Day the Sun Did Not Stand Still: A New Look at Joshua X 8-15," VT 42 (1992): 466-91.

${ }^{33}$ Michael J. Gruenthaner, "Two Sun Miracles of the Old Testament," CBQ 10 (1948): 27190; Fritz, Das Buch Josua, 112; Moshe Weinfeld, "Divine Intervention in War in Ancient Israel and the Ancient Near East," in History, Historiography and Interpretation: Studies in Biblical and Cuneiform Literatures, ed. Hayim Tadmor and Moshe Weinfeld (Jerusalem: Magnes, 1983), 121-47.

${ }^{34}$ John S. Holladay, “The Day(s) the Moon Stood Still," JBL 87 (1968): 166-78, https://doi .org/10.2307/3263346; John H. Walton, "Joshua 10:12-15 and Mesopotamian Celestial Omens," in Faith, Tradition, and History: Old Testament Historiography in Its Near Eastern Context, ed.

This article was published in JBL 138/4 (2019) 741-755, copyright @ 2019 by the Society of Biblical Literature. To purchase copies of this issue or to subscribe to JBL, please contact SBL Customer Service by phone at 866-727-9955 [toll-free in North America] or 404-727-9498, by fax at 404-727-2419, or visit the online SBL Store at www.sbl-site.org. 
Records of celestial omens are well attested in the Neo-Assyrian period, and some have argued that the original form of Josh 10:12-13 may have been a prayer or incantation for the sun and moon to stand in opposition on a day favorable to the Israelites. These arguments are eminently plausible, though in its current form the text links the actions of the sun and moon specifically with YHWH fighting for Israel. ${ }^{35}$ In this light, we must take seriously the arguments of some scholars that the sun and moon represent the gods of Canaan whom YHWH defeats in the heavens as the Israelites defeat the kings on earth. ${ }^{36}$ As noted above, the usual conception in the ancient Near East was that gods and kings engaged in warfare together. ${ }^{37}$ In Josh 10:15, YHWH clearly fights for Israel, but the Canaanites' deities are surprisingly absent unless we view the celestial bodies as representing them. Thus, Matthew Michael argues that the immobilization of the sun and moon demonstrates YHWH's power over the Canaanite deities. ${ }^{38}$ Cooley also draws attention to the parallelism between the sun and moon being suspended in the sky $(10: 12)$ and the Amorite kings' bodies being suspended from trees (10:26). ${ }^{39}$ Further, in Deuteronomy, the celestial bodies are included among forbidden foreign deities (Deut 4:19,17:3), and the influence of Dtr on Joshua has been widely noted. ${ }^{40}$ Although Josh 10:12-15 may originally have been an example of celestial omina, therefore, the current form of the text seems to present the sun and moon as foreign powers rendered immobile, static, and powerless by YHWH. Although sometimes

Alan R. Millard, James K. Hoffmeier, and David W. Baker (Winona Lake, IN: Eisenbrauns, 1994), 181-90; Boling and Wright, Joshua, 284.

${ }^{35}$ It may be that an original prayer or incantation to the sun or moon has been incorporated into the text of Joshua in such a way as to (re)locate the power with YHWH, rather than any other deity, which would be in keeping with the Dtr redactions of the book.

${ }^{36}$ See esp. Matthew Michael, “Twilight of the Gods: Hidden Polemics in Joshua 10:12-14," HS 55 (2014): 59-72; Cooley, Poetic Astronomy, 295-97; James Yu, "Understanding Joshua 10:1214 in Its Context," ExpTim 123 (2012): 581-86. Differently, J. Glen Taylor proposes that the "sunin-Gibeon" is a reference to "Yahweh-in-Gibeon" and argues that the passage demonstrates the existence of a Yahwistic solar cult at Gibeon (Yahweh and the Sun: Biblical and Archaeological Evidence for Sun Worship in Ancient Israel, JSOTSup 111 [Sheffield: Sheffield Academic, 1993], 115-20). I do not follow Taylor's reading here, as it dismisses the role of the moon too easily (though note his defense of this point on 117). This interpretation also overlooks the fact that, in its current Sitz im Leben, Gibeon is not yet a Yahwistic city, so to call it a Yahwistic cult center would be odd. This does not, however, diminish the connections between YHWH, the sun, and Gibeon that are observable elsewhere in the Hebrew Bible.

${ }^{37}$ See n. 31 above. Crouch, War and Ethics, 21-32; Millard C. Lind, Yahweh Is a Warrior: The Theology of Warfare in Ancient Israel (Kitchener, ON: Herald, 1980), 169-71.

${ }^{38}$ Michael, "Twilight of the Gods," 61-64.

${ }^{39}$ Cooley, Poetic Astronomy, 295-97.

${ }^{40}$ E.g., Daniel L. Hawk, "Conquest Reconfigured: Recasting Warfare in the Redaction of Joshua," in Writing and Reading War: Rhetoric, Gender and Ethics in Biblical and Modern Contexts, ed. Brad E. Kelle and Frank Ritchel Ames, SymS 42 (Atlanta: Society of Biblical Literature, 2008), $145-60$.

This article was published in JBL 138/4 (2019) 741-755, copyright @ 2019 by the Society of Biblical Literature. To purchase copies of this issue or to subscribe to JBL, please contact SBL Customer Service by phone at 866-727-9955 [toll-free in North America] or 404-727-9498, by fax at 404-727-2419, or visit the online SBL Store at www.sbl-site.org. 
claimed to support ideas of a divine celestial army, therefore, the celestial bodies here seem to parallel the Canaanite deities defeated in the heavens with the kings defeated on earth. YHWH's demonstrating his power over the sun and moon is more in keeping with Dtr redactions of Joshua than is the idea of their forming part of YHWH's divine army (which is not mentioned in Joshua). Finally, none of the other biblical texts that associate the host of heaven with the sun and moon (Deut $4: 19,17: 3$, Jer $8: 1-3,2$ Kgs 23:5) mentions them acting in a military manner. It seems unlikely, therefore, that the celestial bodies in either Judg 5:20 or Josh 10:1215 formed part of the host of heaven as the divine army of YHWH.

\section{Other References to YHWH's Divine Army in THE Hebrew Bible}

Thus far we have seen that references to the host of heaven and the celestial bodies do not easily correlate with the identification of YHWH's divine army. Yet the biblical texts abound with other references to this divine army, found throughout a range of texts and time periods. A number of these refer to YHWH coming from the south with his retinue in tow (Ps 68:18 [Eng. 17], Deut 33:2-3, Hab 3:2-7); others refer to supernatural chariots (2 Kgs 6:17; cf. 2 Kgs 2:11, 7:6, 13:14, Isa 66:15); and still others refer to individual deities (Rešep, Deber; Hab 3:5), "holy ones" (קדשים; Deut 33:2-3,Zech 14:5), "strong ones/warriors" (גבור/חיל; Joel 2:11, 4:11 [Eng. 3:11]), or "bands/troops" (גדודיו; Job 25:3), that accompany YHWH in his military campaigns. Not one of these references calls YHWH's divine army a "host" (צבא) or the "host of heaven" (צבא השמים). If the host of heaven was a divine army, it never acts as one in the biblical texts, which surely calls for reassessment of this concept.

In contrast to human armies, which comprised units, ranks, and officers, all references to YHWH's divine army emphasize YHWH's sole control. No ranks or generals are mentioned-even where other deities appear in his retinue (Hab 3:5), they are portrayed as part of a much greater whole with no particular role of their own. ${ }^{41}$ This is not surprising, given the focus of the authors. Emphasizing YHWH's sole leadership of the divine army draws attention to YHWH's (self-sufficient) power and authority and accords no importance to any other divine figure. This was theologically necessary and also conceptually logical, as the history of Israel and Judah demonstrated that generals were a dangerous phenomenon, often able to use their military strength to oust the kings and replace them. Such a threat was inconceivable for $\mathrm{YHWH}$, and thus his sole leadership of his army is emphasized.

The lack of "host" terminology to refer to YHWH's divine army is surprising, as it stands in complete contrast to portrayals of the human armies of Israel and Judah, which are regularly called a "host." Furthermore, there is not just a lack of

${ }^{41}$ The only possible reference-if read that way-is Josh 5:14. 
"host" terminology in the references to the divine army but a seeming lack of standardization of terminology overall. A few texts reflect similarities, such as the chariots of Deut 33:2-3 and Ps 68:18 [Eng. 17] and the "holy ones" of Deut 33:2-3 and Zech 14:5, which may well indicate textual dependence, but no military terminology appears as standard across all the texts. Rather, their unifying elements seem to be their diversity, the fluidity of the concept of YHWH's army, and the emphasis on the supernatural. The authors used terms that suited either them or their contexts to describe YHWH's army, often adding in a supernatural element, such as innumerable numbers (Deut 33:2-3), fire (2 Kgs 6:17), or whirlwind (Isa 66:15). The authors' aim is to portray YHWH's army not as mirroring human armies but as superseding them. While unsurprising, this suggests that the avoidance of human "host" terminology when describing YHWH's army may reflect attempts to distinguish or differentiate between the human and divine armies. Whereas the human "hosts" were vulnerable to defeat, open to deposing their kings, and comparatively small, YHWH's divine army was not. Given that the biblical texts report that Israel and Judah were defeated, for example, by Philistia (1 Sam 4), Aram (1 Kgs 15:20-21, 22:29-36, 2 Kgs 8:28-29, 10:32-35), Moab (2 Kgs 3:26-28), Edom (2 Kgs 8:20-22, 16:6), Assyria (2 Kgs 17; 18-19), Egypt (1 Kgs 14:25-26, 2 Kgs 23:29-34), Babylon (2 Kgs 24-25), each other (2 Kgs 14:1114), and were also prone to military coups (1 Kgs 16:9-17, 2 Kgs 9, 2 Kgs 11:4-12) and internal struggles (e.g., 2 Sam 18, 1 Kgs 12, 2 Kgs 16:5-10), it may have been necessary to portray YHWH's divine army differently, so that YHWH as its commander would not appear tainted by defeats on earth.

\section{What Were the Host of Heaven?}

Contrary to common assumptions, the host of heaven are not portrayed as YHWH's divine army in the biblical texts. The natural question then is, What were they? Just a glance at a dictionary entry on the heavenly host will demonstrate the difficulty of answering this question. The host of heaven could function as a divine council (1 Kgs 22:19-23), as a heavenly court or a heavenly congregation praising YHWH in the heavens (Pss 103:19-22, 148:1-4, Neh 9:6; cf. Dan 8:10-14), as the celestial bodies whom Israel was exhorted not to worship (Deut 4:19, 17:3, Jer 8:1-3, 2 Kgs 23:5), or as the gods of the other nations (e.g., Deut 4:19, Isa 24:22; cf. 34:4). ${ }^{42}$ Most often, however, they appear completely undefined, with no identifying characteristics (e.g., 2 Kgs 17:16; 21:3, 5; 23:4; Zeph 1:4-5; Jer 19:13; Ps 33:6). The majority of references to the host in the Hebrew Bible simply designate them

\footnotetext{
${ }^{42}$ The parallelism between the "host of the height" (צבא המרום) and the "kings of the earth" in Isa 24:22 suggests that the host here are the gods of the nations that YHWH will punish along with the kings.
}

This article was published in JBL 138/4 (2019) 741-755, copyright @ 2019 by the Society of Biblical Literature. To purchase copies of this issue or to subscribe to JBL, please contact SBL Customer Service by phone at 866-727-9955 [toll-free in North America] or 404-727-9498, by fax at 404-727-2419, or visit the online SBL Store at www.sbl-site.org. 
as צבא השמים, with no further distinctive features whatsoever. Either the authors presumed that their audiences knew what the host were (or could readily disambiguate the polysemous terminology) and so needed no explanation, or the identity of the host has been deliberately obscured, stripping them of any names, characteristics, or traditions that they may otherwise have had.

What is evident from these texts is that the host of heaven could be portrayed in a number of ways, enacting a number of roles in different contexts. They thus elude simple definition. Their fluidity and lack of definition permit the biblical authors to use them in service of a variety of arguments, all of which involve either calling on Israel to worship YHWH alone or elevating YHWH above other divine beings. The unifying feature of the host of heaven is that they always point to YHWH and to behavior that Israel is called to enact.

Accordingly, a brief comment on the epithet "YHWH of Hosts" may be in order. Significant debate exists over the origins and meaning of this epithet; its meaning is almost as elusive as the host themselves. In biblical terms, "YHWH of Hosts" appears connected first with Shiloh and the ark of the covenant and then with Jerusalem. In addition, the epithet crops up in strategic places in the books of Samuel, which may suggest that this association derives from later editing. ${ }^{43}$ Johannes C. de Moor refers to an epithet of Rešep-ršp șb -found at Ugarit to argue that "YHWH of Hosts" should be translated "YHWH of armies." ${ }^{44}$ It is clear that Rešep was associated with warfare and did become part of the Yahwistic tradition (e.g., Hab 3:5, Deut 32:24, Ps 78:48), ${ }^{45}$ but I am aware of only this one reference to "Rešep of Hosts." It seems implausible, therefore, that this one reference could explain all the meanings of the centuries-long usage of the epithet "YHWH of Hosts" in the Hebrew Bible and ancient Israelite tradition. Although "YHWH of Hosts" appears connected with warfare in, for example, 1 Sam 17:45, Tryggve N. D.

\footnotetext{
${ }^{43}$ It appears most notably in 1 Sam 1:3, 11; 15:2; 17:45; 2 Sam 6:18; 7:8, 26, 27, while the longer epithet "YHWH of Hosts, enthroned over the cherubim" occurs twice, in 1 Sam 4:4, 2 Sam 6:2; see Antony F. Campbell, 1 Samuel, FOTL 7 (Grand Rapids: Eerdmans, 2003), 66. As early as the late nineteenth century, Henry Preserved Smith suggested that these epithets may belong to later strata of 1-2 Samuel (A Critical and Exegetical Commentary on the Books of Samuel, ICC [1899; repr., Edinburgh: T\&T Clark, 1977], 5). Although many scholars accept the view that the epithet "YHWH of Hosts" dates back to premonarchic Shiloh, the possibility does exist that the term was retrospectively connected with Shiloh, perhaps on the basis of the ark traditions and the intent of the authors to demonstrate that Jerusalem had replaced Shiloh. Yet, given Shiloh's destruction in Iron I and a lack of early Israelite texts, it is difficult to determine whether the terminology יהוה צבאות originated there.

${ }^{44}$ This has an added effect of implying that the host of heaven should be translated "army of heaven"; see Johannes C. de Moor, The Rise of Yahwism: The Roots of Israelite Monotheism, 2nd ed., BETL 91 (Leuven: Leuven University Press, 1997), 180-81.

${ }^{45}$ See esp. Maciej M. Münnich, The God Resheph in the Ancient Near East, ORA 11 (Tübingen: Mohr Siebeck, 2013), 215-37; Susanne Rudnig-Zelt, "JHWH und Rešep: Zu JHWHs Umgang mit einem syrischen Pestgott,” VT 65 (2015): 247-64, esp. 254-56.
}

This article was published in JBL 138/4 (2019) 741-755, copyright @ 2019 by the Society of Biblical Literature. To purchase copies of this issue or to subscribe to JBL, please contact SBL Customer Service by phone at 866-727-9955 [toll-free in North America] or 404-727-9498, by fax at 404-727-2419, or visit the online SBL Store at www.sbl-site.org. 
Mettinger argues that its primary aspect was royal, referring to and signifying YHWH enthroned in Jerusalem. ${ }^{46}$ Differently, James L. Crenshaw connects the epithet with creation and views it as a polemic against Marduk. ${ }^{47}$ Siegfried Kreuzer, however, argues for more fluidity in the concept, permitting that different biblical texts may reflect different meanings and usages that developed over time. ${ }^{48}$ Given the depth of meaning inherent in the epithet and the concepts of YHWH it invokes, Kreuzer's argument seems the most persuasive. If the host of heaven and the epithet "YHWH of Hosts" are connected, then we might concede that the role or interpretation of the host of heaven is likely to be similarly fluid and open to development over the course of Israel and Judah's history.

\section{Conclusions}

The preceding discussion has sought to demonstrate that, in the texts available to us, the host of heaven do not act as a divine army. This observation cannot fully rule out the possibility that the host could have acted in a military manner, but it calls for a reassessment of arguments claiming that the host were consistently YHWH's divine army. Appropriate caution is needed, therefore, when dealing with the host in biblical interpretation. Recognizing that the host of heaven are not portrayed as a divine army in the biblical texts allows us to explore their other portrayals and to better understand the relationship between the human armies and theological conceptions of the divine army. In sum, it is likely that there was no fixed conception of, or terminology for, YHWH's divine army in the Hebrew Bible. It may well be that the biblical authors deliberately did not use the term "host" in order to avoid associating YHWH's divine army too closely with the weaknesses of the human armies.

\footnotetext{
${ }^{46}$ Tryggve N. D. Mettinger, In Search of God: The Meaning and Message of the Everlasting Names, trans. Frederick H. Cryer (Philadelphia: Fortress, 1988), 123-57; see also J. P. Ross, "Yahweh Șebāâôt in Samuel and Psalms," VT 17 (1967): 76-92.

${ }^{47}$ James L. Crenshaw, "YHWH Șebeāôt Š Šemô: A Form-Critical Analysis,” ZAW 81 (1969): 156-75.

${ }^{48}$ Siegfried Kreuzer, “Zebaoth: Der Thronende," VT 56 (2006): 347-62.
} 